\title{
Peroxisome Proliferator-Activated Receptors and Shock State
}

\author{
Emanuela Esposito ${ }^{1,2, \star}$, Salvatore Cuzzocrea ${ }^{2,3}$, and Rosaria Meli ${ }^{1}$ \\ ${ }^{1}$ Department of Experimental Pharmacology, University of Naples "Federico II", Naples, \\ Italy; ${ }^{2}$ IRCCS Centro Neurolesi "Bonino-Pulejo", Messina, Italy; ${ }^{3}$ Department of Clinical \\ and Experimental Medicine and Pharmacology, Torre Biologica, Policlinico Universitario, \\ Messina, Italy \\ E-mail: emaesposito@unina.it
}

Received October 26, 2006; Revised December 13, 2006; Accepted December 13, 2006; Published December 28, 2006

Peroxisome proliferator-activated receptors (PPARs) are members of the nuclear hormone receptor superfamily of ligand-activated transcription factors that are related to retinoid, steroid, and thyroid hormone receptors. Three isotypes of PPARs have been identified: alpha, beta/delta, and gamma, encoded by different genes and distributed in various tissues.

PPARs are implicated in the control of inflammatory responses and in energy homeostasis and, thus, can be defined as metabolic and anti-inflammatory transcription factors. They exert anti-inflammatory effects by inhibiting the induction of proinflammatory cytokines, adhesion molecules, and extracellular matrix proteins, or by stimulating the production of anti-inflammatory molecules. Moreover, PPARs modulate the proliferation, differentiation, and survival of immune cells. This review presents the current state of knowledge regarding the involvement of PPARs in the control of inflammatory response, and their potential therapeutic applications in several types of shock, as well as hemorrhagic, septic, and nonseptic shock.

KEYWORDS: PPARs, sepsis, nonseptic, hemorrhagic shock

\section{INTRODUCTION}

Peroxisome proliferator-activated receptors (PPARs) were identified during the last decade and were classified as orphan members of the nuclear receptor superfamily[1,2]. These receptors, which are related to retinoid, steroid, and thyroid hormone receptors[3], bind to and are activated by fatty acids, eicosanoids, and numerous structurally dissimilar xenobiotics, known collectively as peroxisome proliferators.

PPARs are now considered as regulators of lipid and lipoprotein metabolism, possible molecular determinants of metabolic disorders, and controllers of cellular differentiation and cancer development[4]. Moreover, they play a role in inflammatory response and inflammation-related disorders[5,6]. In this article, we will focus on the new insights indicating an involvement of PPARs in several types of shock, as well as hemorrhagic, septic, and zymosan-induced shock. These findings highlight the potential of natural and synthetic PPAR agonists as therapeutic targets for the treatment of shock and related disorders. 


\section{ISOFORMS AND STRUCTURAL FEATURES OF PPARS}

To date, three subtypes of PPARs, encoded by separate genes, have been identified: PPAR- $\alpha$, PPAR- $\gamma$, and PPAR- $\beta$ (also called - $\delta$ ) $[7,8,9]$. Most tissues in humans and rodents have all three receptor types, although there is considerable variability in the relative expression. PPAR- $\alpha$ is mostly present in tissues characterized by high rates of fatty acid catabolism, such as liver, kidney, heart, and muscle[10], whereas PPAR- $\gamma$ is highly expressed in adipose tissue[11] and is also detected in mammary gland and many other tissues[12,13]. Moreover, PPARs are expressed in immunological and vascular wall cell types; PPAR- $\alpha$ and PPAR- $\gamma$ are expressed in primary cultures of endothelial[14,15,16,17,18] and smooth muscle cells[19,20], and in monocyte/macrophages[21,22,23,24]. Whereas PPAR- $\alpha$ is present in isolated human monocytes and its expression increases during the differentiation process, PPAR- $\gamma$ is not detectable in human monocytes, but is strongly induced on differentiation[21]. In addition, PPAR- $\alpha$ and PPAR- $\gamma$ colocalize with specific markers of macrophages in the subendothelial region and in the lipid core of atherosclerotic lesions, smooth muscle cells, and foam cells $[15,16,24,25,26]$. The third member of the PPAR family, PPAR- $\delta$, is expressed in a wide range of tissues including heart, adipose tissue, brain, intestine, muscle, spleen, lung, and adrenal glands[10,11].

PPARs and other class 1 nuclear receptors, i.e., retinoic acid receptor (RARs), the tyroid hormone receptors (TRs), and the steroid and xenobiotic receptors (SXR), possess similar structural and functional features. Principally, four functional domains have been identified and called A/B, C, D, and E/F. First, the Nterminal region A/B allows a ligand-independent activation domain function 1 (AF-1)[27] responsible for the phosphorylation of PPAR. Second, the C domain or the DNA binding domain (DBD) promotes the binding of PPAR to the peroxisome proliferator response element (PPRE) in the promoter region of target genes[28]. Third, the D site is a docking domain for cofactors and, at last, the E domain or ligand-binding domain (LBD) is responsible for ligand specificity and activation of PPAR binding to the PPRE, which increases the expression of targeted genes. Recruitment of PPAR cofactors to assist the gene transcription processes is carried out by the ligand-dependent activation function 2 (AF-2), which is located in the E/F domain[29].

\section{MECHANISM OF ACTION}

Once activated by a ligand, PPARs form a heterodimer with the retinoid X receptor (RXRs), a member of the class 2 nuclear receptors that are activated by binding of 9-cis retinoic acid[30]. The interaction with the RXR allows the recruitment of a set of cofactors and the binding of the heterodimer to the PPRE in the promoter region of target genes, modulating the transcription[31,32,33]. In the absence of a ligand, to prevent PPAR/RXR binding to DNA, high-affinity complexes are formed between the inactive PPAR/RXR heterodimers and corepressor molecules, such as nuclear receptor corepressor or silencing mediator for retinoic receptors.

Binding of a ligand to the heterodimer results in the release of the corepressor from the complex, which in turn results in the binding of the activated heterodimer to the response element in the promoter region of the relevant target gene(s), resulting in either the activation or suppression of a specific gene[34].

After binding of the ligand, the recruitment of coactivator proteins, i.e., CREB-binding protein, and p300 [35] can also be required for transcriptional interaction of PPAR- $\gamma$ with motifs in the PPRE. The limited availability of these coactivators might inhibit the activation of the transcription factors AP-1, NF- $\kappa \mathrm{B}$, and STAT, and consequently, inhibits the proinflammatory gene expression[36].

PPARs can also repress gene transcription by negatively interfering with the NF- $\kappa \mathrm{B}$, STAT, and AP-1 signaling pathways in a DNA-binding independent manner[15,19,21,22,37]. Negative interference by PPARs with these signal transduction pathways is likely due to a combination of protein-protein interaction and cofactor squelching, as has been previously demonstrated for other members of the nuclear receptor family, such as the retinoic acid and glucocorticoid receptors[38]. PPARs interfere with the AP-1 and NF-kB signaling pathway by preventing the binding of AP-1 and NF- $\mathrm{B}$ proteins to their target sequences[14,15]. Furthermore, PPARs interact with c-Jun[39], as well as with p65[40]. 
This transrepression activity likely constitutes the mechanistic basis for the anti-inflammatory properties of PPARs.

\section{SYNTHETIC AND NATURAL LIGANDS OF PPARS}

PPARs are activated by fatty acids and fatty acid-derived molecules, as well as by a number of pharmacological and synthetic compounds. PPAR- $\alpha$, which controls genes relevant to the regulation of lipid metabolism and inflammatory process, was the first member of the PPAR family identified, and it is believed to be solely responsible for the effects of the peroxisomal proliferators[41]. To date, more than 70 compounds, including synthetic hypolipidemic fibrate drugs (Wy-14,643, nafenopin, clofibrate)[42], phthalate plasticizers (monoethylhexylphthalate), chlorinated hydrocarbons, and herbicides, along with endogenous hormones and fatty acids (arachidonic acid), have been identified as PPAR- $\alpha$ agonists[43,44,45].

In particular, PPAR- $\alpha$ is activated by naturally occuring eicosanoids derived from arachidonic acid through the lipoxygenase pathway, such as 8-S-hydroxyeicosatetraenoic acid (8-S-HETE) and leukotriene B4 (LTB4)[44,45,46], and by oxidized low-density lipoproteins (OxLDL)-derived oxidized phospholipids[47].

It has been demonstrated that PPAR- $\gamma$ can be activated by arachidonic acid metabolites derived from the cycloxygenase and lipoxygenase pathways, such as 15-deoxy- $D$-12,14-prostaglandin J2 (15d-PGJ2) and 15HETE[48,49,50]. Recent findings have revealed a crucial role of 12/15-lipoxygenase in the generation of endogenous PPAR- $\gamma$ ligands[51]. In addition, fatty acid-derived components of OxLDL, such as 9hydroxyoctadecadienoic acid (9-HODE) and 13-hydroxyoctadecadienoic acid (13-HODE), are natural ligands for PPAR- $\gamma[50]$. Finally, the antidiabetic glitazones, currently used as insulin sensitizers, are synthetic highaffinity ligands for PPAR- $\gamma[52]$. A novel series of trisubstituited isoxazoles, as PPAR- $\delta$-selective agonists, was investigated and optimized. Furthermore, some fibrates have recently been described as specific ligands for the PPAR- $\delta$ subtype[53,54,55].

In addition to fibrates and glitazones, other pharmacological compounds have been identified as PPAR activators. Inhibition of cycloxygenase by NSAIDs (nonsteroidal anti-inflammatory drugs) constitutes a clinical approach for the treatment of inflammatory states. Lehmann et al.[56] have demonstrated that certain NSAIDs, including indomethacin and ibuprofen, are activators of PPAR- $\gamma$, acting in the micromolar range. These data are consistent with the observation that indomethacin can promote terminal adipocyte differentiation of various preadipocyte cell lines in vitro[57]. The molecular basis underlying this adipogenic action could thus be mediated via activation of PPAR- $\gamma$. Certain NSAIDs are also ligands for the PPAR- $\alpha$ form[56]. Several NSAIDs have marked effects on peroxisome activity in rodent hepatocytes when used either in vitro or in vivo[58,59], and it appears likely that these effects are mediated by PPAR- $\alpha$ activation.

\section{SHOCK STATES}

Sepsis is defined as infection with evidence of systemic inflammation, consisting of two or more of the following: increased or decreased temperature or leucocyte count, tachycardia, and rapid breathing. Septic shock is sepsis with hypotension that persists after resuscitation with intravenous fluid. Normally, the immune and neuroendocrine systems tightly control the local inflammatory process to eradicate invading pathogens. When this local control mechanism fails, systemic inflammation occurs, converting the infection to sepsis, severe sepsis, or septic shock[60].

Sepsis can be caused by infection with Gram-negative bacteria, Gram-positive bacteria, fungi (and particularly Candida), or viruses.

Sepsis may also occur in the absence of these challenges, and in these cases, microbial toxins, particularly Gram-negative bacterial endotoxin (LPS), and endogenous cytokine production have been implicated as initiators and mediators[61,62]. Although activation of the immune system during microbial invasion is generally protective, septic shock develops in a significant number of patients as a consequence of a poorly regulated immune response to pathogens. 
Despite recent progress in antibiotics and critical care therapy, sepsis is still associated with a high mortality rate $(\sim 40-50 \%)$, even when appropriate therapy is administered to the patient.

Many mechanisms are involved in the pathophysiology of septic shock, including the release of cytokines; the activation of neutrophils, monocytes, and microvascular endothelial cells; as well as the activation of neuroendocrine reflex and plasma protein cascade systems (complement system, the intrinsic and extrinsic pathways of coagulation, and the fibrinolytic system).

Several studies have shown that hemorrhagic shock results in a rapid decrease in cardiac output and organ blood flow[63]. The depressed organ perfusion and excessive production of proinflammatory mediators play an important role in the development of multiple organ dysfunction (MOD) following hemorrhagic shock[64,65]. It has been reported that systemic IL-6 levels increase following trauma-hemorrhage, and a sustained elevation in plasma IL-6 levels is correlated with the evolving organ dysfunction[66,67,68]. IL-6 has been described as a multifunctional cytokine, produced during the acute phase by macrophages, $\mathrm{T}$ and $\mathrm{B}$ cells, and nonimmune cells, such as myocytes or endothelial cells[69,70,71].

\section{PPARS AND SEPTIC SHOCK}

Various studies have demonstrated that PPAR- $\gamma$ ligands reduce the multiple organ injury/dysfunction caused by shock. In a model of Gram-negative shock (Escherichia coli endotoxin), pretreatment of rats with 15dPGJ2 prevented the multiple organ failure (MOF) (i.e., hepatic and pancreatic dysfunction/injury) induced by endotoxin[72,73]. The PPAR- $\gamma$ antagonist GW9662 partially reverted the beneficial effects of 15d-PGJ2, demonstrating that the mechanisms of the protective effects of $15 \mathrm{~d}-\mathrm{PGJ} 2$ are partly PPAR- $\gamma$ dependent.

In a model of polymicrobial shock, pretreatment with 15d-PGJ2 attenuated the organ injury/dysfunction caused by coadministration of E. coli-LPS or Streptococcus aureus peptidoglycan in rats. There is evidence that both G+ and G- bacteria have been isolated in the blood of a large portion of septic patients and these polymicrobial infections often have higher mortality than infections due a single bacterium. The protection afforded by the cyclopentenone prostaglandin was reduced by GW9662[74]. Moreover, in a rat model of polymicrobial sepsis induced by cecal ligation and puncture, treatment with 15d-PGJ2 or ciglitazone ameliorated hypotension and vascular injury; reduced neutrophil infiltration in lung, colon, and liver; and reduced the elevation of cytokine in plasma. The reduction of the inflammatory process was also associated with significant improvement in animal survival. The beneficial effects of these PPAR- $\gamma$ ligands were reported to be secondary to a negative modulation of NF- $\mathrm{KB}$ and AP-1 signal transduction pathways[75].

It is widely accepted that $15 \mathrm{~d}-\mathrm{PGJ} 2$ attenuates the NF- $\mathrm{KB}-$ mediated transcriptional activation of many proinflammatory genes by PPAR- $\gamma$-dependent and -independent mechanisms[76]. For instance, 15d-PGJ2 attenuates the formation of the cytokines, such as tumor necrosis factor- $\alpha$ (TNF- $\alpha$ ) and IL-12[77], the expression of vascular cell adhesion molecule-1 (VCAM-1) and intercellular adhesion molecule-1 (ICAM1)[78], and the expression of the inducible proinflammatory proteins, COX-2, cytosolic phospholipase A2[79], and inducible nitric oxide synthase (iNOS)[22,80]. There is, however, also evidence that 15d-PGJ2 may enhance the formation of the proinflammatory chemokine IL-8 in human macrophages/monocytes stimulated with endotoxin in a PPAR- $\gamma$-dependent fashion[81].

However, the role of PPAR- $\gamma$ activation and the precise molecular mechanisms of 15d-PGJ2 have not been fully determined in sepsis. Administration of 15d-PGJ2 improved survival, and reduced lung injury and neutrophil trafficking to lung and small intestine in mice subjected to endotoxic shock[82]. 15d-PGJ2 enhanced the PPAR- $\gamma$ function in the lung, decreased NF- $\kappa B$ activity, and enhanced the expression of the cytoprotective protein HSP70. The heat shock response is a highly conserved cellular defense mechanism to injury, which is characterized by the increased expression of chaperone proteins that provide cytoprotection from inflammatory insults, including oxidative stress, viral infection, and ischemia-reperfusion injury $[83,84]$. $15 \mathrm{~d}-\mathrm{PGJ} 2$ and activation of PPAR- $\gamma$ led to enhancement of the heat shock response in the lung as demonstrated by the increased expression of HSP70, which correlated well with improvement of lung injury. These findings are in agreement with previous in vitro reports demonstrating that 15d-PGJ2 may induce 
expression of HSPs. Maggi and colleagues have proposed that the ability of 15d-PGJ2 to block cytokineinduced iNOS in macrophages is associated with the expression of HSP70[85].

Moreover, the therapeutic effect of $15 \mathrm{~d}-\mathrm{PGJ} 2$ may be consequent to prevention of gene expression of molecules controlling neutrophil rolling, firm adhesion, and transmigration. In vitro, PPAR- $\gamma$ activation suppressed the VCAM and the ensuing leukocyte recruitment in endothelial cells $[86,87,88]$. Similarly, in vivo treatment with PPAR- $\gamma$ ligands suppress neutrophil recruitment in major organs in rats with polymicrobial sepsis[75]. Several cellular mechanisms, including the mode of gene regulation and signal transduction, may account for the anti-inflammatory properties of $15 \mathrm{~d}-\mathrm{PGJ} 2$ in endotoxic shock. Activation of NF- $\mathrm{BB}$, a critical factor in the coordination of both innate and adaptive immune responses in sepsis, is rapid and occurs within minutes after the microbial challenge[89,90]. The duration and the degree of NF- $\kappa \mathrm{B}$ activity appear to correlate with the severity of the inflammatory response and to persist longer in nonsurviving than surviving patients with acute sepsis[91]. It has been proposed, in fact, that PPAR- $\gamma$ may modulate expression of inflammatory genes by direct transrepression. PPAR- $\gamma$ inhibited expression of the iNOS by direct interaction with CREB-binding protein, thus limiting its availability for NF- $\kappa$ B and AP-1 transcription[36,92].

The effect of PPAR- $\gamma$ ligands on the inflammatory response linked to shock appears to be complex and dependent on the specific PPAR- $\gamma$ ligands used, corepressors or coactivators involved, the mode of immune cell activation, and the mediators that are measured.

More recently, hearts from mice treated with LPS were examined for altered expression of PPAR- $\gamma$ and coactivators[93]. LPS-treated mice exhibited reduced expression of all isoforms of PPAR- $\gamma$ and RXRa and thyroid receptor (TR). Additionally, the coactivators CBP/P300, steroid coactivator (SRC-1) and SRC-3, TRassociated protein 220, and PPAR- $\gamma$ coactivator (PGG-1) were reduced. Because the nuclear receptors, cofactors, and the genes that they regulate are important in myocardial fatty acid oxidation, reduced expression of these factors may contribute to altered myocardial fatty acid metabolism and contractility in endotoxic shock[93]. The cardiovascular hypodynamic phase of septic shock is associated with downregulation of PPAR- $\gamma$ expression on the endothelium of thoracic aortas and in the bronchial epithelium in rats[75]. Conversely, it has been demonstrated[94] that in porcine white blood cells, PPAR- $\gamma$ protein expression increased twofold over basal in response to acute endotoxemia, suggesting a different regulation of PPAR- $\gamma$ expression in various cell types.

Septic shock is often associated with vascular damage, hemostasis activation, and development of disseminated intravascular coagulation. In fact, in human volunteers, endotoxin injection is related to prolonged coagulation activation and endothelial injury[95]. It has been demonstrated that during septic shock, an alteration of nitric oxide pathway occurs. The reduction of endothelial constitutive NOS (eNOS) expression and overexpression of vascular smooth muscle cell iNOS contribute to hypotension and observed alteration of tissue perfusion[96,97,98].

On the basis of anti-inflammatory effects of PPAR- $\alpha$ agonists and their prevention of coagulation activation, very recent studies suggest a possible role for PPAR- $\alpha$ in the modulation of sepsis-induced tissue and vascular injury.

Fenofibrate, a well-known PPAR- $\alpha$ agonist, has been shown to inhibit up-regulation of monocyte tissue factor (TF) expression in monocytes and macrophages, negatively interfering with the AP-1 and/or NF- $\mathrm{kB}$ pathway[99]. Moreover, this synthetic drug inhibits transcription of cytokine-induced VCAM-1 gene, preventing leukocyte adhesion and associated endothelial injury, at least in part via inhibition of the NF- $\mathrm{kB}$ pathway[15,100].

Recently, for the first time, evidence was provided that PPAR- $\alpha$ activation has a protective effect in septic shock, using a well-characterized rabbit endotoxin-induced shock model[101]. This effect was associated with an improvement in endothelial relaxation function and a decrease in coagulation activation (monocyte $\mathrm{TF}$ expression).

As previously reported[102,103], LPS induces a decreased sensitivity to phenylephrine (PE) that is

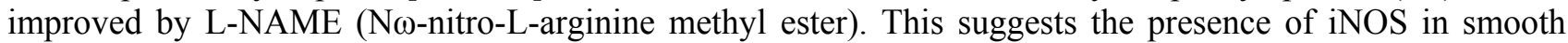
muscle cells induced by LPS. Moreover, removal or damage of endothelial cells can also trigger the induction of iNOS in vascular smooth muscle cells[104]. In rabbit shock model, the LPS-induced decrease in sensitivity to $\mathrm{PE}$ in smooth muscle cell was restored by fenofibrate treatment, suggesting reduction in iNOS 
expression[101]. The mechanism underlying the decrease in iNOS expression in smooth muscle cell, after fenofibrate treatment, is unknown, but may be due at least in part to restoration of endothelial structure and function induced by PPAR- $\alpha$ activation or direct effect of PPAR- $\alpha$ activation.

Several data show that LPS is responsible for abnormal coupling between acetylcholine (Ach) endothelial receptor and eNOS. Oxidative stress has been incriminated in this uncoupling $[105,106,107]$ and PPAR- $\alpha$ activation prevents this effect, increasing antioxidant enzyme release, i.e., catalase and superoxide dismutase[108,109].

Few studies examined the role of PPAR- $\delta$ in the inflammatory responses. Ding et al.[110] investigated the effects of PPAR- $\delta$ and its synthetic ligand GW0742 on TNF- $\alpha$ production in cultured cardiomyocytes. This study indicated that a PPAR- $\delta$-selective ligand inhibited LPS-induced TNF- $\alpha$ production from cardiomyocytes. Moreover, activation of PPAR- $\delta$ abrogated LPS-induced degradation of I $\kappa \mathrm{Bs}$, thus suppressing LPS-induced NF- $\kappa$ B activities. Therefore, PPAR- $\delta$ could be an important determinant of TNF- $\alpha$ expression via the NF- $\mathrm{KB}$ signaling pathway, thus serving as therapeutic targets to attenuate inflammation.

Moereover, Letavernier et al.[111] recently showed that wild-type mice that were given the specific PPAR- $\delta$ ligand L-165041 before renal ischemia were completely protected against renal dysfunction. This protective effect was accompanied by a significant reduction in medullary necrosis, apoptosis, and inflammation. On the basis of in vitro studies, PPAR- $\delta$ ligands seem to exert their role by activating the antiapoptotic Akt signaling pathway. These results pointed to PPAR- $\delta$ as a remarkable new target for preconditioning strategies.

\section{PPARS AND NONSEPTIC SHOCK}

Zymosan-induced shock is an animal model used for improving and understanding the pathophysiological mechanism of MOF. Zymosan, a nonbacterial, nonendotoxic agent, produces acute peritonitis and MOF characterized by functional and structural changes in liver, intestine, lung, and kidneys[112,113,114].

Recent studies have shown that macrophages play an important role in zymosan-induced inflammatory processes by activating the synthesis of cytokines and proinflammatory mediators[114,115]. Zymosan administration in the peritoneal cavity is associated with systemic hypotension, high peritoneal and plasma levels of nitric oxide, maximal cellular infiltration, exudate formation, and cyclooxygenase activity[116].

Recently, treatment of mice with rosiglitazone ( 1 and $6 \mathrm{~h}$ after zymosan) attenuated the peritoneal exudation and the migration of polymorphonuclear (PMN) cells. Rosiglitazone also reduced the lung, liver, and pancreatic injury and renal dysfunction caused by zymosan as well as the increase in myeloperoxidase (MPO) activity and malondialdehyde concentrations in the lung and intestine. Immunohistochemical analysis for iNOS, nitrotyrosine, and poly(adenosine diphosphate-ribose) revealed positive staining in lung and intestine tissues obtained from zymosan-treated mice. The degree of staining for these markers was clearly reduced in tissue sections obtained from zymosan-treated mice that received rosiglitazone. The protective effects of rosiglitazone was related to activation of the PPAR- $\gamma$ receptor, since a PPAR- $\gamma$ antagonist, GW 9662, abolished the protective effect of rosiglitazone[117].

Moreover, Marzocco et al.[118] investigated the effect of 15d-PGJ2 on this nonseptic shock model in mice. This study provides the first evidence that pretreatment of mice with 15d-PGJ2 attenuates the development of induced peritonitis, reducing the PMNs infiltration and tissue damage of the intestine, as assessed by MPO activity and histological examination, respectively. Moreover, the cyclopentenone prostaglandin reduces NO both in the peritoneal exudates and plasma. The reduction of NO levels by $15 \mathrm{~d}-$ PGJ2 may contribute to the attenuation of the formation of nitrotyrosine in the ileum from zymosan-treated mice.

These findings support the potential use of PPAR- $\gamma$ ligands as therapeutic agents in the therapy of conditions associated with nonseptic shock.

\section{PPARS AND HEMORRHAGIC SHOCK}


Hemorrhagic shock is a condition characterized by rapid and significant loss of intravascular volume, which may lead sequentially to hemodynamic instability, decreases in oxygen delivery, decreased tissue perfusion, cellular hypoxia, organ damage, and can be rapidly fatal.

Severe hemorrhage impairs the delivery of oxygen and nutrients to the tissues, and produces a state of shock that induces a cascade of proinflammatory cytokines that are associated with immunosuppression, hemodynamic depression, and organ dysfunction[119,120]. The therapeutic goals for hemorrhagic shock are to stop bleeding and to restore intravascular volume[121].

Abdelrahman and colleagues[122] recently investigated the role of PPAR- $\gamma$ in organ injury associated with hemorrhagic shock. In particular, the authors showed that 15d-PGJ2 attenuated the renal, hepatic, lung, and intestinal injury/dysfunction associated with hemorrhage and resuscitation. In contrast, 15d-PGJ2 did not affect the circulatory failure (delayed fall in mean arterial blood pressure) associated with hemorrhagic shock. However, a pretreatment regimen was used and further studies employing a therapeutic (post-treatment) administration of $15 \mathrm{~d}-\mathrm{PGJ} 2$ are warranted.

In this model, GW9662 not only reversed the protective effects afforded by $15 \mathrm{~d}-\mathrm{PGJ} 2$, but also augmented the degree of liver injury caused by hemorrhage and resuscitation[122]. This finding, therefore, indicates that hemorrhage and resuscitation results in the release of endogenous PPAR- $\gamma$ ligands and that the amounts of these ligands released are sufficient to protect the liver against the organ injury associated with hemorrhagic shock, but not septic shock[123].

\section{CONCLUSIONS}

Many mechanisms are involved in the pathophysiology of shock state, including the release of cytokines; the activation of neutrophils, monocytes, and microvascular endothelial cells; as well as the activation of neuroendocrine reflex and plasma protein cascade systems (Fig. 1). There is extensive complementary and synergistic interaction of the different components in the progression of shock to MOD and/or MOF. Timely, aggressive resuscitation to preserve organ function remains a fundamental principle in the care of shock. The specific treatment is directed at identifying and treating the underlying disorder.

PPARs, known at the beginning as regulators of lipid and lipoprotein metabolism, more recently have been identified as important players in the metabolism of lipid-derived inflammatory mediators and in inflammation-related pathologies. The reported observations and new knowledge about the role of PPAR agonists on inflammatory response[124,125], and epithelial dysfunction indicate that they could be effective in the treatment of shock and related disorders. 


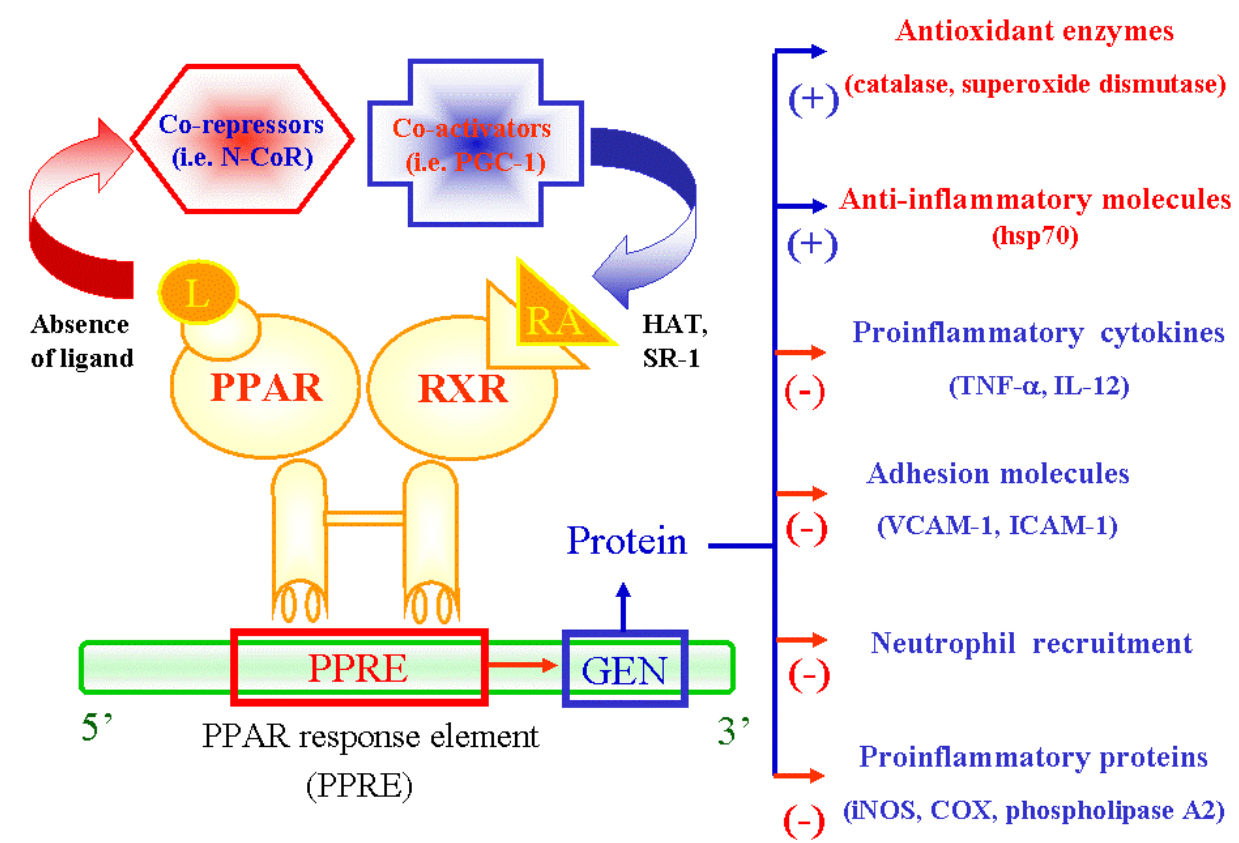

FIGURE 1. Similar to other nuclear hormone receptors, PPAR acts as a ligand-activated transcription factor. PPAR- $\alpha$, when activated after binding with specific ligand, interacts with RXR and regulates the expression of target genes. These genes are also involved in the catabolism of fatty acids. Conversely, PPARs are activated by different ligands and affect the expression of genes involved in the storage of fatty acids. PPAR- $\beta$ is only weakly activated by fatty acids, prostaglandins, and leukotrienes, and has no known physiologically relevant ligand.

\section{REFERENCES}

1. Isseman, I. and Green, S. (1990) Activation of a member of the steroid hormone receptor superfamily by peroxisome proliferators. Nature 347, 645-650.

2. Dreyer, C., Krey, G., Keller, H., Givel, F., Helftenbein, G., and Wahli, W. (1992) Control of the peroxisomal betaoxidation pathway by a novel family of nuclear hormone receptors. Cell $\mathbf{6 8}, 879-887$.

3. Evans, R.M. (1988) The steroid and thyroid hormone receptor superfamily. Science 240, 889-895.

4. Kota, B.P., Huang, T.H., and Roufogalis, B.D. (2005) An overview on biological mechanisms of PPARs. Pharmacol. Res. 51, 85-94.

5. Chinetti, G., Fruchart, J.C., and Staels, B. (2000) Peroxisome proliferator-activated receptors (PPARs): nuclear receptors at the crossroads between lipid metabolism and inflammation. Inflamm. Res. 49, 497-505.

6. Youssef, J. and Badr, M. (2004) Role of peroxisome proliferator-activated receptors in inflammation control. $J$. Biomed. Biotechnol. 2004, 156-166.

7. Greene, M.E., Blumberg, B., McBride, O.W., Yi, H.F., Kronquist, K., Kwan, K., Hsieh, L., Greene, G., and Nimer, S.D. (1995) Isolation of the human peroxisome proliferator activated receptor gamma cDNA: expression in hematopoietic cells and chromosomal mapping. Gene Expr. 4, 281-299.

8. Sher, T., Yi, H.F., McBride, O.W., and Gonzalez, F.J. (1993) cDNA cloning, chromosomal mapping, and functional characterization of the human peroxisome proliferator activated receptor. Biochemistry 132, 5598-5604.

9. Yoshikawa, T., Brkanac, Z., Dupont, B.R., Xing, G.Q., Leach, R.J., and Detera-Wadleigh, S.D. (1996) Assignment of the human nuclear hormone receptor, NUC1 (PPARD), to chromosome 6p21.1-p21.2. Genomics 35, 637-638.

10. Braissant, O., Foufelle, F., Scotto, C., Dauca, M., and Wahli, W. (1996) Differential expression of peroxisome proliferator-activated receptors: tissue distribution of PPAR-alpha, -beta, and -gamma in the adult rat. Endocrinology 137, 354-366.

11. Tontonoz, P., Hu, E., Graves, R.A., Budavari, A.I., and Spiegelman, B.M. (1994) mPPAR $\gamma 2$ : tissue-specific regulator of an adipocyte enhancer. Genes Dev. 8, 1224-1234.

12. Braissant, O. and Wahli, W. (1998) Differential expression of peroxisome proliferator-activated receptor- $\alpha$, $\beta$, and $\gamma$ during rat embryonic development. Endocrinology 139, 2748-2754.

13. Mansen, A., Guardiola-Diaz, H., Rafter, J., Branting, C., and Gustafsson, J.A. (1996) Expression of the peroxisome proliferator-activated receptor (PPAR) in the mouse colonic mucosa. Biochem. Biophys. Res. Commun. 222, 844-851.

14. Delerive, P., Martin-Nizard, F., Chinetti, G., Trottein, F., Fruchart, J.C., Najib, J., Duriez, P., and Staels, B. (1999) 
PPAR activators inhibit thrombin-induced endothelin-1 production in human vascular endothelial cells by inhibiting the AP-1 signaling pathway. Circ. Res. 85, 394-402.

15. Marx, N., Sukhova, G., Collins, T., Libby, P., and Plutzky, J. (1999) PPARa activators inhibit cytokine-induced vascular cell adhesion molecule-1 expression in human endothelial cells. Circulation 99, 3125-3131.

16. Inoue, I., Shino, K., Noji, S., Awata, T., and Katayama, S. (1998) Expression of peroxisome proliferator-activated receptor $\alpha(\mathrm{PPAR} \alpha)$ in primary cultures of human vascular endothelial cells. Biochem. Biophys. Res. Commun. 246, 370-374.

17. Marx, N., Bourcier, T., Sukhova, G., Libby, P., and Plutzky, J. (1999) PPAR $\gamma$ activation in human endothelial cells increases plasminogen activator inhibitor type-I expression. Arterioscler. Thromb. Vasc. Biol. 19, 5465-5551.

18. Xin, X., Yang, S., Kowalski, J., and Gerritsen, M.E. (1999) Peroxisome proliferator-activated receptor gamma ligands are potent inhibitors of angiogenesis in vitro and in vivo. J. Biol. Chem. 274, 9116-9121.

19. Staels, B., Koenig, W., Habib, A., Merval, R., Lebret, M., Pineda-Torra, I., Delerive, P., Fadel, A., Chinetti, G., Fruchart, J.C., Najib, J., Maclouf, J., and Tedgui, A. (1998) Activation of human aortic smooth-muscle cells is inhibited by PPAR $\alpha$ but not by PPAR $\gamma$ activators. Nature 393, 790-793.

20. Marx, N., Schönbeck, U., Lazar, M.A., Libby, P., and Plutzky, J. (1999) Peroxisome proliferator-activated receptor gamma activators inhibit gene expression and migration in human vascular smooth muscle cells. Circ. Res. 83, 10971103 .

21. Chinetti, G., Griglio, S., Antonucci, M., Pineda Torra, I., Delerive, P., Majd, Z., Fruchart, J.C., Chapman, J., Najib, J., and Staels, B. (1998) Activation of peroxisome proliferator-activated receptors aand ginduces apoptosis of human monocyte-derived macrophages. J. Biol. Chem. 273, 25573-25580.

22. Ricote, M., Li, A.C., Willsson, T.M., Kelly, C.J., and Glass, C.K. (1998) The peroxisome proliferator-activated receptor- $\alpha$ is a negative regulator of macrophage activation. Nature 391, 79-82.

23. Tontonoz, P., Nagy, L., Alvarez, J., Thomazy, V., and Evans, R. (1998) PPAR $\gamma$ promotes monocyte/macrophage differentiation and uptake of oxidized LDL. Cell 93, 241-252.

24. Marx, N., Sukhova, G., Murphy, C., Libby, P., and Plutzky, J. (1998) Macrophages in human atheroma contain PPARgamma: differentiation-dependent peroxisomal proliferator-activated receptor gamma (PPARgamma) expression and reduction of MMP-9 activity through PPARgamma activation in mononuclear phagocytes in vitro. Am. J. Pathol. 153, 17-23.

25. Ricote, M., Huang, J., Fajas, L., Li, A., Welch, J., Najib, J., Witztum, J.L., Auwerx, J., Palinski, W., and Glass, CK. (1998) Expression of the peroxisome proliferator-activated receptor $\gamma$ (PPAR $\gamma$ ) in human atherosclerosis and regulation in macrophages by colony stimulating factors and oxidized low density lipoprotein. Proc. Natl. Acad. Sci. U. S. A. 95, 7614-7619.

26. Chinetti, G., Gbaguidi, G.F., Griglio, S., Mallat, Z., Antonucci, M., Poulain, P., Chapman, J., Fruchart, J.C., Tedgui, A., Najib-Fruchart, J., and Staels, B. (2000) CLA-1/SR-BI is expressed in atherosclerotic lesion macrophages and regulated by activators of peroxisome proliferator-activated receptors. Circulation 101, 2411-2417.

27. Werman, A., Hollenberg, A., Solanes, G., Bjorbaek, C., Vidal-Puig, A.J., and Flier, J.S. (1997) Ligand-independent activation domain in the $\mathrm{N}$ terminus of peroxisome proliferator-activated receptor gamma (PPAR- $\gamma$ ). Differential activity of PPAR- $\gamma 1$ and 2 isoforms and influence of insulin. J. Biol. Chem. 272, 20230-20235.

28. Ijpenberg, A., Jeannin, E., Wahli, W., and Desvergne, B. (1997) Polarity and specific sequence requirements of peroxisome proliferator-activated receptor (PPAR)/retinoid X receptor heterodimer binding to DNA. J. Biol. Chem. 272, 20108-20117.

29. Berger, J. and Moller, D.E. (2002) The mechanisms of action of PPARs. Annu. Rev. Med. 53, 409-435.

30. Desvergne, B. and Wahli, W. (1999) Peroxisome proliferator-activated receptors: nuclear control of metabolism. Endocr. Rev. 20, 649-688.

31. Nolte, R.T., Wisely, G.B., Westin, S., Cobb, J.E., Lambert, M.H., Kurokawa, R., Rosenfeld, M.G., Willson, T.M., Glass, C.K., and Milburn, M.V. (1998) Ligand binding and co-activator assembly of the peroxisome proliferatoractivated receptor-g. Nature 395, 137-143.

32. Kliewer, S.A., Umesono, K., Noonan, D.J., Heyman, R.A., and Evans, R.M. (1992) Convergence of 9-cis retinoic acid and peroxisome proliferator signalling pathways through heterodimer formation of their receptors. Nature 358, 771-774.

33. Palmer, C.N., Hsu, M.H., Griffin, H.J., and Johnson, E.F. (1995) Novel sequence determinants in peroxisome proliferator signaling. J. Biol. Chem. 270, 16114-16121.

34. Bishop-Bailey, D. (2000) Peroxisome proliferator-activated receptors in the cardiovascular system. Br. J. Pharmacol. 129, 823-834.

35. Li, M., Pascual, G., and Glass, C.K. (2000) Peroxisome proliferator-activated receptor $\gamma$-dependent repression of the inducible nitric oxide synthase gene. Mol. Cell. Biol. 20, 4699-4707.

36. Zingarelli, B. and Cook, J.A. (2005) Peroxisome proliferator-activated receptor-gamma is a new therapeutic target in sepsis and inflammation. Shock 23, 393-399.

37. Zhou, Y.C. and Waxman, D.J. (1999) Cross-talk between janus kinase-signal transducer activator of transcription (JAK-STAT) and peroxisome proliferator-activated receptor alpha (PPARalpha) signaling pathways. J. Biol. Chem. 274, 2672-2681.

38. Kamei, Y., Xu, L., Heinzel, T., Torchia, J., Kurokawa, R., Gloss, B., Lin, S.C., Heyman, R.A., Rose, D.W., Glass, 
C.K., and Rosenfeld, M.G. (1996) A CBP integrator complexmediates transcriptional activation and AP-1 inhibition by nuclear receptors. Cell 85, 403-414.

39. Sakai, M., Matsushima-Hibiya, Y., Nishizawa, M., and Nishi, S. (1995) Suppression of rat glutathione transferase P expression by peroxisome proliferators: interaction between Jun and peroxisome proliferatoractivated receptor a. Cancer Res. 53, 5370-5376.

40. Delerive, P., De Bosscher, K., Besnard, S., Vanden Berghe, W., Peter, J.M., Gonzalez, F.J., Fruchart, J.C., Tedgui, A., Haegeman, G., and Staels, B. (1999) PPAR $\alpha$ negatively regulates the vascular wall inflammatory gene response by negative cross-talk with transcription factors NF- $k$ B and AP-1. J. Biol. Chem. 274, 32048-32054.

41. Clark, R.B. (2002) The role of PPARs in inflammation and immunity. J. Leukoc. Biol. 71, 388-400.

42. Forman, B.M., Chen, J., and Evans, R.M. (1997) Hypolipidemic drugs, polyunsaturated fatty acids, and eicosanoids are ligands for peroxisome proliferator-activated receptors $a$ and d. Proc. Natl. Acad. Sci. U. S. A. 94, 312-317.

43. Kliewer, S.A., Sundseth, S.S., Jones, S.A., Brown, P.J., Wisely, G.B., Koble, C.S., Devchand, P., Wahli, W., Willson, T.M., Lenhard, J.M., and Lehmann, J.M. (1997) Fatty acids and eicosanoids regulate gene expression through direct interactions with peroxisome proliferator-activated receptors alpha and gamma. Proc. Natl. Acad. Sci. U. S. A. 94, 4318-4323.

44. Krey, G., Braissant, O., L'Horset, F., Kalkhoven, E., Perroud, M., Parker, M.G., and Wahli, W. (1997) Fatty acids, eicosanoids, and hypolipidemic agents identified as ligands of peroxisome proliferator-activated receptors by coactivator-dependent receptor ligand assay. Mol. Endocrinol. 11, 779-791.

45. Zhou, Y.C. and Waxman, D.J. (1998) Activation of peroxisome proliferator-activated receptors by chlorinated hydrocarbons and endogenous steroids. Environ. Health Perspect. 106(Suppl 4), 983-988.

46. Devchand, P.R., Keller, H., Peters, J.M., Vazquez, M., Gonzalez, F.J., and Wahli, W. (1996) The PPAR $\alpha$-leukotriene B4 pathway to inflammation control. Nature 384, 39-43.

47. Delerive, P., Furman, C., Teissier, E., Fruchart, J-C., Duriez, P., and Staels, B. (2000) Oxidized phospholipids activate PPAR $\alpha$ in a phospholipase A2-dependant manner. FEBS Lett. 471, 34-38.

48. Forman, B.M., Tontonoz, P., Chen, J., Brun, R.P., Spiegelman, B.M., and Evans, R.M. (1995) 15-Deoxy-D12,14 prostaglandin $\mathrm{J} 2$ is a ligand for the adipocyte determination factor PPAR $\gamma$. Cell 83, 803-812.

49. Kliewer, S.A., Lenhard, J.M., Willson, T.M., Patel, I., Morris, D.C., and Lehmann, J.M. (1995) A prostaglandin J2 metabolite binds peroxisome proliferator-activated receptor $\gamma$ and promotes adipocyte differentiation.Cell 83, 813819.

50. Nagy, L., Tontonoz, P., Alvarez, J.G.A., Chen, H., and Evans, R.M. (1998) Oxidized LDL regulates macrophage gene expression through ligand activation of PPAR $\gamma$. Cell 93, 229-240.

51. Huang, J.T., Welch, J.S., Ricote, M., Binder, C.J., Willson, T.M., Kelly, C., Witztum, J.L., Funk, C.D., Conrad, D., and Glass, CK. (1999) Interleukin-4-dependent production of PPAR- $\gamma$ ligands in macrophages by 12/15 lipoxygenase. Nature 400, 378-382.

52. Lehmann, J., Moore, L., Smith-Oliver, A., Wilkison, W., Willson, T., and Kliewer, S. (1995) An antidiabetic thiazolidinedione is a high affinity ligand for peroxisome proliferator-activated receptor gamma (PPAR gamma). $J$. Biol. Chem. 270, 12953-12956.

53. Willson, T.M., Brown, P.J., Sternbach, D.D., and Henke, B.R. (2000) The PPARs: from orphan receptors to drug discovery. J. Med. Chem. 43, 527-550.

54. Epple, R., Azimioara, M., Russo, R., Xie, Y., Wang, X., Cow, C., Wityak, J., Karanewsky, D., Bursulaya, B., Kreusch, A., Tuntland, T., Gerken, A., Iskandar, M., Saez, E., Martin Seidel, H., and Tian, S.S. (2006) 3,4,5Trisubstituted isoxazoles as novel PPARdelta agonists. Part 2. Bioorg. Med. Chem. Lett. 16, 5488-5492.

55. Pelton, P. (2006) GW-501516 GlaxoSmithKline/Ligand. Curr. Opin. Investig. Drugs 7, 360-370.

56. Lehmann, J.M., Lenhard, J.M., Oliver, B.B., Ringold, G.M., and Kliewer, S.A. (1997) Peroxisome proliferatoractivated receptors $\alpha$ and $g$ are activated by indomethacin and other non-steroidal anti-inflammatory drugs. J. Biol. Chem. 272, 3406-3410.

57. Knight, D.M., Chapman, A.B., Navre, M., Drinkwater, L., Bruno, J.J., and Ringold, G.M. (1987) Requirements for triggering of adipocyte differentiation by glucocorticoids and indomethacin. Mol. Endocrinol. 1, 36-43.

58. Foxworthy, P.S., Perry, D.N., and Eacho, P.I. (1993) Induction of peroxisomal beta-oxidation by nonsteroidal antiinflammatory drugs. Toxicol. Appl. Pharmacol. 118, 271-274.

59. Ayrton, A.D., Ioannides, C., and Parke, D.V. (1991) Induction of the cytochrome P450 I and IV families and peroxisomal proliferation in the liver of rats treated with benoxaprofen. Possible implications in its hepatotoxicity. Biochem. Pharmacol. 42, 109-115.

60. Annane, D., Bellissant, E., and Cavaillon, J.M. (2005) Septic shock. Lancet 365, 63-78.

61. Wheller, A.P. and Bernard, G.R. (1999) Treating patients with severe sepsis. N. Engl. J. Med. 340, $207-214$.

62. Hardaway, R.M. (2000) A review of septic shock. Am. Surg. 66, 22-29.

63. Ba, Z.F., Wang, P., Koo, D.J., Cioffi, W.G., Bland, K.I., and Chaudry, I.H. (2000) Alterations in tissue oxygen consumption and extraction after trauma and hemorrhagic shock. Crit. Care Med. 28, 2837-2842.

64. Ayala, A., Ertel, W., and Chaudry, I.H. (1996) Trauma-induced suppression of antigen presentation and expression of major histocompatibility class II antigen complex in leukocytes. Shock 5, 79-90.

65. Jarrar, D., Chaudry, I.H., and Wang, P. (1999) Organ dysfunction following hemorrhage and sepsis: mechanisms and therapeutic approaches. Int. J. Mol. Med. 4, 575-583. 
66. Diodato, M.D., Knoferl, M.W., Schwacha, M.G., Bland, K.I., and Chaudry, I.H. (2001) Gender differences in the inflammatory response and survival following haemorrhage and subsequent sepsis. Cytokine 14, 162-169.

67. Angele, M.K., Schwacha, M.G., Ayala, A., and Chaudry, I.H. (2000) Effect of gender and sex hormones on immune responses following shock. Shock 14, 81-90.

68. Kuebler, J.F., Jarrar, D., Bland, K.I., Rue, L., 3rd, Wang, P., and Chaudry, I.H. (2003) Progesterone administration after trauma and hemorrhagic shock improves cardiovascular responses. Crit. Care Med. 31, 1786-1793.

69. Akira, S., Hirano, T., Taga, T., and Kishimoto, T. (1990) Biology of multifunctional cytokines: IL 6 and related molecules (IL 1 and TNF). FASEB J. 4, 2860-2867.

70. Simpson, R.J., Hammacher, A., Smith, D.K., Matthews, J.M., and Ward, L.D. (1997) Interleukin-6: structurefunction relationships. Protein Sci. 6, 929-955.

71. Ancey, C., Corbi, P., Froger, J., Wijdenes, J., Gascan, H., Potreau, D., and Lecron, J.C. (2002) Secretion of IL-6, IL11 and LIF by human cardiomyocytes in primary culture. Cytokine 18, 199-205.

72. Collin, M. and Thiemermann, C. (2003) The PPAR-gamma ligand 15-deoxy(delta12,14) prostaglandin J2 reduces the liver injury in endotoxic shock. Eur. J. Pharmacol. 476, 257-258.

73. Collin, M., Patel, N.S., Dugo, L., and Thiemermann, C. (2004) Role of peroxisome proliferator-activated receptorgamma in the protection afforded by 15-deoxydelta12,14 prostaglandin $\mathrm{J} 2$ against the multiple organ failure caused by endotoxin. Crit. Care Med. 32, 826-831.

74. Dugo, L., Collin, M., Cuzzocrea, S., and Thiemermann, C. (2004) 15d-prostaglandin J(2) reduces multiple organ failure caused by wall-fragment of Gram- positive and Gram-negative bacteria Eur. J. Pharmacol. 498, $295-301$.

75. Zingarelli, B., Sheehan, M., Hake, P.W., O'Connor, M., Denenberg, A., and Cook, J.A. (2003) Peroxisome proliferator activator receptor-gamma ligands, 15-deoxy-Delta(12,14)-prostaglandin J2 and ciglitazone, reduce systemic inflammation in polymicrobial sepsis by modulation of signal transduction pathways J. Immunol. 171, $6827-6837$.

76. Straus, D.S. and Glass, C.K. (2001) Cyclopentenone prostaglandins: new insights on biological activities and cellular targets. Med. Res. Rev. 21, 185-210.

77. Drew, P.D. and Chavis, J.A. (2001) The cyclopentone prostaglandin 15-deoxydelta $(12,14)$ prostaglandin J2 represses nitric oxide, tumour necrosis factor-alpha, and IL-12 production by microglial cells. J. Neuroimmunol. 115, $28-35$.

78. Pasceri, V., Wu, H.D., Willerson, J.T., and Yeh, E.T. (2000) Modulation of vascular inflammation in vitro and in vivo by peroxisome proliferatoractivated receptor-gamma activators. Circulation 101, 235-238.

79. Tsubouchi, Y., Kawahito, Y., Kohno, M., Inoue, K., Hla, T., and Sano, H. (2001) Feedback control of the arachidonate cascade in rheumatoid synoviocytes by 15-deoxy-delta(12,14)-prostaglandin J2. Biochem. Biophys. Res. Commun. 283, 750-755.

80. Colville-Nash, P.R., Qureshi, S.S., Willis, D., and Willoughby, D.A. (1998) Inhibition of inducible nitric oxide synthase by peroxisome proliferatoractivated receptor agonists: correlation with induction of heme oxygenase 1 . $J$. Immunol. 161, 978-984.

81. Zhang, X., Wang, J.M., Gong, W.H., Mukaida, N., and Young, H.A. (2001) Differential regulation of chemokine gene expression by 15-deoxy-delta 12,14 prostaglandin J2. J. Immunol. 166, 7104-7111.

82. Kaplan, J.M., Cook, J.A., Hake, P.W., O’Connor, M., Burroughs, T.J., and Zingarelli, B. (2005) 15-deoxy-d12,14prostaglandin J2 (15d-PGJ2), a peroxisome proliferator activated receptor g ligand, reduces tissue leukosequestration and mortality in endotoxic shock. Shock 24, 59-65.

83. DeMaio, A.D. (1999) Heat shock proteins: facts, thoughts, and dreams. Shock 11, 1-12.

84. Wong, H.R. (1998) Potential protective role of the heat shock response against sepsis. New Horiz. 6, $194-200$.

85. Maggi, L.B., Jr., Sadeshi, H., Weigand, C., Scarim, A.L., Heitmeier, M.R., and Corbett, J.A. (2000) Antiinflammatory actions of 15-deoxy-delta 12,14-prostaglandin J2 and troglitazone: evidence for heat shock-dependent and -independent inhibition of cytokine-induced inducible nitric oxide synthase expression. Diabetes 49, 346-355.

86. Jackson, S.M., Parhami, F., Xi, X.P., Berliner, J.A., Hsueh, W.A., Law, R.E., and Demer, L.L. (1999) Peroxisome proliferator-activated receptor activators target human endothelial cells to inhibit leukocyte-endothelial cell interaction. Arterioscler. Thromb. Vasc. Biol. 19, 2094-2104.

87. Verrier, E., Wang, L., Wadham, C., Dalboni, M.A., Blecher, S., and Salomao, R. (2004) PPAR $\gamma$ agonists ameliorate endothelial cell activation via inhibition of diacylglycerol-protein kinase C signaling pathway: role of diacylglycerol kinase. Circ. Res. 94, 1515-1522.

88. Wang, N., Verna, L., Chen, N.G., Chen, J., Li, H., Forman, B.M., and Stemerman, M.B. (2002) Constitutive activation of peroxisome proliferator-activated receptor- $\gamma$ suppresses pro-inflammatory adhesion molecules in human vascular endothelial cells. J. Biol. Chem. 277, 34176-34181.

89. Zingarelli, B., Sheehan, M., and Wong, H.R. (2003) Nuclear factor-kB as a therapeutic target in critical care medicine. Crit. Care Med. 31, S105-S111.

90. Sheehan, M., Wong, H.R., Hake, P.W., Malhotra, V., O'Connor, M., and Zingarelli, B. (2002) Parthenolide, an inhibitor of the nuclear factor-kB pathway, ameliorates cardiovascular derangement and outcome in endotoxic shock in rodents. Mol. Pharmacol. 61, 953-963.

91. Bohrer, H., Qiu, F., Zimmermann, T., Zhang, Y., Jllmer, T., Mannel, D., Bottiger, B.W., Stern, D.M., Waldherr, R., Saeger, H.D., Ziegler, R., Bierhaus, A., Martin, E., and Nawroth, P.P. (1997) Role of NF-kB in the mortality of sepsis. J. Clin. Invest. 100, 972-985. 
92. Li, M., Pascual, G., and Glass, C.K. (2000) Peroxisome proliferator-activated receptor g-dependent repression of the inducible nitric oxide synthase gene. Mol. Cell. Biol. 20, 4699-4707.

93. Feingold, K., Kim, M.S., Shigenaga, J., Moser, A., and Grunfeld, C. (2004) Altered expression of nuclear hormone receptors and coactivators in mouse heart during the acutephase response. Am. J. Physiol. Endocrinol. Metab. 286, E201-E207.

94. Leininger, M.T., Portocarrero, C.P., and Houseknecht, K.L. (1999) Peroxisome proliferator-activated receptor gamma1 expression in porcine white blood cells: dynamic regulation with acute endotoxemia. Biochem. Biophys. Res. Commun. 263, 749-753.

95. Hotchkiss, R.S. and Karl, I.E. (2003) The pathophysiology and treatment of sepsis. N. Engl. J. Med. 348, $138-150$.

96. Connelly, L., Madhani, M., and Hobbs, A.J. (2005) Resistance to endotoxic shock in endothelial nitric-oxide synthase (eNOS) knock-out mice: a pro-inflammatory role for eNOS-derived no in vivo. J. Biol. Chem. 280, 10040-10046.

97. Madhani, M., Scotland, R.S., MacAllister, R.J., and Hobbs, A.J. (2003) Vascular natriuretic peptide receptor-linked particulate guanylate cyclases are modulated by nitric oxide-cyclic GMP signalling. Br. J. Pharmacol. 139, 12891296.

98. Hobbs, A.J., Higgs, A., and Moncada, S. (1999) Inhibition of nitric oxide synthase as a potential therapeutic target. Annu. Rev. Pharmacol. Toxicol. 39, 191-220.

99. Neve, B.P., Corseaux, D., Chinetti, G., Zawadzkib, C., Fruchart, J.C., Duriez, P., Staels, B., and Jude, B. (2001) PPAR $\alpha$ agonists inhibit tissue factor expression in human monocytes and macrophages. Circulation 103, $207-212$.

100. Delerive, P., Gervois, P., Fruchart, J.C., and Staels, B. (2000) Induction of IkBa expression as a mechanism contributing to the anti-inflammatory activities of peroxysome proliferator-activated receptor-a activators. J. Biol. Chem. 47, 36703-36707.

101. Wiel, E., Lebuffe, G., Robin, E., Gasan, G., Corseaux, D., Tavernier, B., Jude, B., Bordet, R., and Vallet, B. (2005) Pretreatment with peroxysome proliferator-activated receptor a agonist fenofibrate protects endothelium in rabbit Escherichia coli endotoxin-induced shock. Intensive Care Med. 31, 1269-1279.

102. Leclerc, J., Pu, Q., Corseaux, D., Haddad, E., Decoene, C., Bordet, R., Six, I., Jude, B., and Vallet, B. (2000) A single endotoxin injection in rabbit causes prolonged blood vessel dysfunctions and procoagulant state. Crit. Care Med. 28, 3672-3678.

103. Wiel, E., Pu, Q., Corseaux, D., Robin, E., Bordet, R., Lund, N., Jude, B., and Vallet, B. (2000) Effect of L-arginine on endothelial injury and hemostasis in rabbit endotoxin shock. J. Appl. Physiol. 89, 1811-1818.

104. Adeagbo, A.S.O. and Triggle, C.R. (1993) Interactions of nitric oxide synthase inhibitors and dexamethasone with alpha-adrenoceptor-mediated responses in rat. Br. J. Pharmacol. 109, 495-501.

105. Mugge, A., Elwell, J.H., Peterson, T.E., Hofmeyer, T.G., Heistad, D.D., and Harrison, D.G. (1991) Chronic treatment with polyethylene-glycolated superoxide dismutase partially restores endothelium-dependent vascular relaxations in cholesterol-fed rabbits. Circ. Res. 69, 1293-1300.

106. Keaney, J.F., Jr., Xu, A., Cunningham, D., Jackson, T., Frei, B., and Vita, J.A. (1995) Dietary probucol preserves endothelial function in cholesterol-fed rabbits by limiting vascular oxidative stress and superoxide generation. J. Clin. Invest. 95, 2520-2529.

107. Griendling, K.K., Sorescu, D., Lassegue, B., and Ushio-Fukai, M. (2000) Modulation of protein kinase activity and gene expression by reactive oxygen species and their role in vascular physiology and pathophysiology. Arterioscler. Thromb. Vasc. Biol. 20, 2175-2183.

108. Yoo, H.Y., Chang, M.S., and Rho, H.M. (1999) Induction of the rat $\mathrm{Cu} / \mathrm{Zn}$ superoxide dismutase gene through the peroxisome proliferator-responsive element by arachidonic acid. Gene 234, 87-91.

109. Arnaiz, S.L., Travacio, M., Llesuy, S., and Boveris, A. (1995) Hydrogen peroxide metabolism during peroxysome proliferation by fenofibrate. Biochim. Biophys. Acta 1272, 175-180.

110. Ding, G., Cheng, L., Qin, Q., Frontin, S., and Yang, Q. (2006) PPARdelta modulates lipopolysaccharide-induced TNFalpha inflammation signalling in cultured cardiomyocytes. J. Mol. Cell Cardiol. 40, 821-828.

111. Letavernier, E., Perez, J., Joye, E., Bellocq, A., Fouqueray, B., Haymann, J.P., Heudes, D., Wahli, W., Desvergne, B., and Baud, L. (2005) Peroxisome proliferator-activated receptor beta/delta exerts a strong protection from ischemic acute renal failure. J. Am. Soc. Nephrol. 16, 2395-2402.

112. Demling, R., Nayac, U., Ikegami, K., and La Londe, C. (1994) Comparison between lung and liver peroxidation and mortality after zymosan peritonitis in the rats. Shock 2, 222-227.

113. van Bebber, I.P., Boekholz, W.K., Goris, R.J., Schillings, P.H., Dinges, H.P., Bahrami, S., Redl, H., and Schlag, G. (1989) Neutrophil function and lipid peroxidation in a rat model of multiple organ failure. J. Surg. Res. 47, 471-475.

114. Volman, T.J., Hendriks, T., Verhofstad, A.A., Kullberg, B.J., and Goris, R.J. (2002) Improved survival of TNFdeficient mice during the zymosan-induced multiple organ dysfunction syndrome. Shock 17, 468-472.

115. Cuzzocrea, S., Sautebin, L., De Sarro, G., Costantino, G., Rombola, L., Mazzon, E., Ialenti, A., De Sarro, A., Ciliberto, G., Di Rosa, M., Caputi, A.P., and Thiemermann, C. (1999) Role of interleukin-6 in a nonseptic shock model induced by zymosan. Eur. Cytokine Netw. 10, 191-203.

116. Cuzzocrea, S., Mazzon, E., Di Paola, R., Genovese, T., Serraino, I., Dugo, L., Cuzzocrea, E., Fulia, F., Caputi, A.P., and Salvemini, D. (2004) Protective effects of M40401, a selective superoxide dismutase mimetic, on zymosaninduced nonseptic shock. Crit. Care Med. 32, 157-167.

117. Cuzzocrea, S., Pisano, B., Dugo, L., Ianaro, A., Patel, N.S., Di Paola, R., Genovese, T., Chatterjee, P.K., Fulia, F., 
Cuzzocrea, E., Di Rosa, M., Caputi, A.P., and Thiemermann, C. (2004) Rosiglitazone, a ligand of the peroxisome proliferator-activated receptor-gamma, reduces the development of nonseptic shock induced by zymosan in mice. Crit. Care Med. 32, 457-466.

118. Marzocco, S., Di Paola, R., Mazzon, E., Genovese, T., Britti, D., Pinto, A., Autore, G., and Cuzzocrea, S. (2005). The cyclopentenone prostaglandin 15-deoxyD12,14-prostaglandin J2 attenuates the development of zymosan-induced shock. Intensive Care Med. 31, 693-700.

119. Shires, T., Coln, D., Carrico, J., and Lightfoot, S. (1964) Fluid therapy in hemorrhagic shock. Arch. Surg. 8, 688-693.

120. Healey, M.A., Davis, R.E., Liu, F.C., Loomis, W.H., and Hoyt, D.B. (1998) Lactated ringers is superior to normal saline in a model of massive hemorrhage and resuscitation. J. Trauma 45, 894-898.

121. Gutierrez, G., Reines, H.D., and Wulf-Gutierrez, M.E. (2004) Clinical review: hemorrhagic shock. Crit. Care 8, 373381.

122. Abdelrahman, M., Collin, M., and Thiemermann, C. (2004) The peroxisome proliferator-activated receptor-gamma ligand 15-deoxyDelta12,14 prostaglandin J2 reduces the organ injury in hemorrhagic shock. Shock 22, 555-561.

123. Collin, M., Abdelrahman, M., and Thiemermann, C. (2004) Endogenous ligands of PPAR-gamma reduce the liver injury in haemorrhagic shock. Eur. J. Pharmacol. 486, 233-235.

124. Glass, C.K. and Ogawa, S. (2006) Combinatorial roles of nuclear receptors in inflammation and immunity. Nat. Rev. Immunol. 6, 44-55.

125. Michalik, L. and Wahli, W. (2006) Involvement of PPAR nuclear receptors in tissue injury and wound repair. J. Clin. Invest. 116, 598-606.

\section{This article should be cited as follows:}

Esposito, E., Cuzzocrea, S., and Meli, R. (2006) Peroxisome proliferator-activated receptors and shock state. TheScientificWorldJOURNAL 6, 1770-1782. DOI 10.1100/tsw.2006.298. 

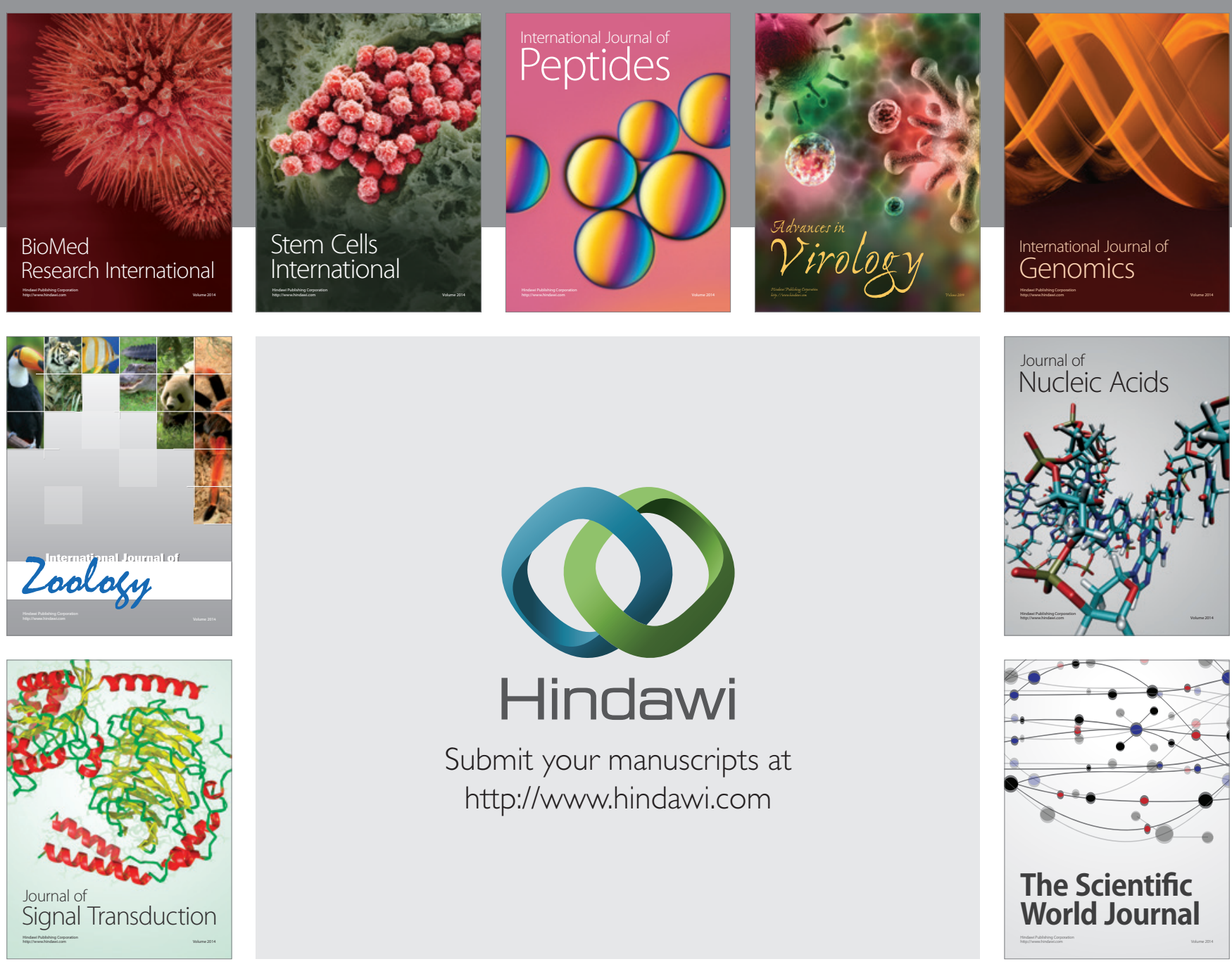

Submit your manuscripts at

http://www.hindawi.com
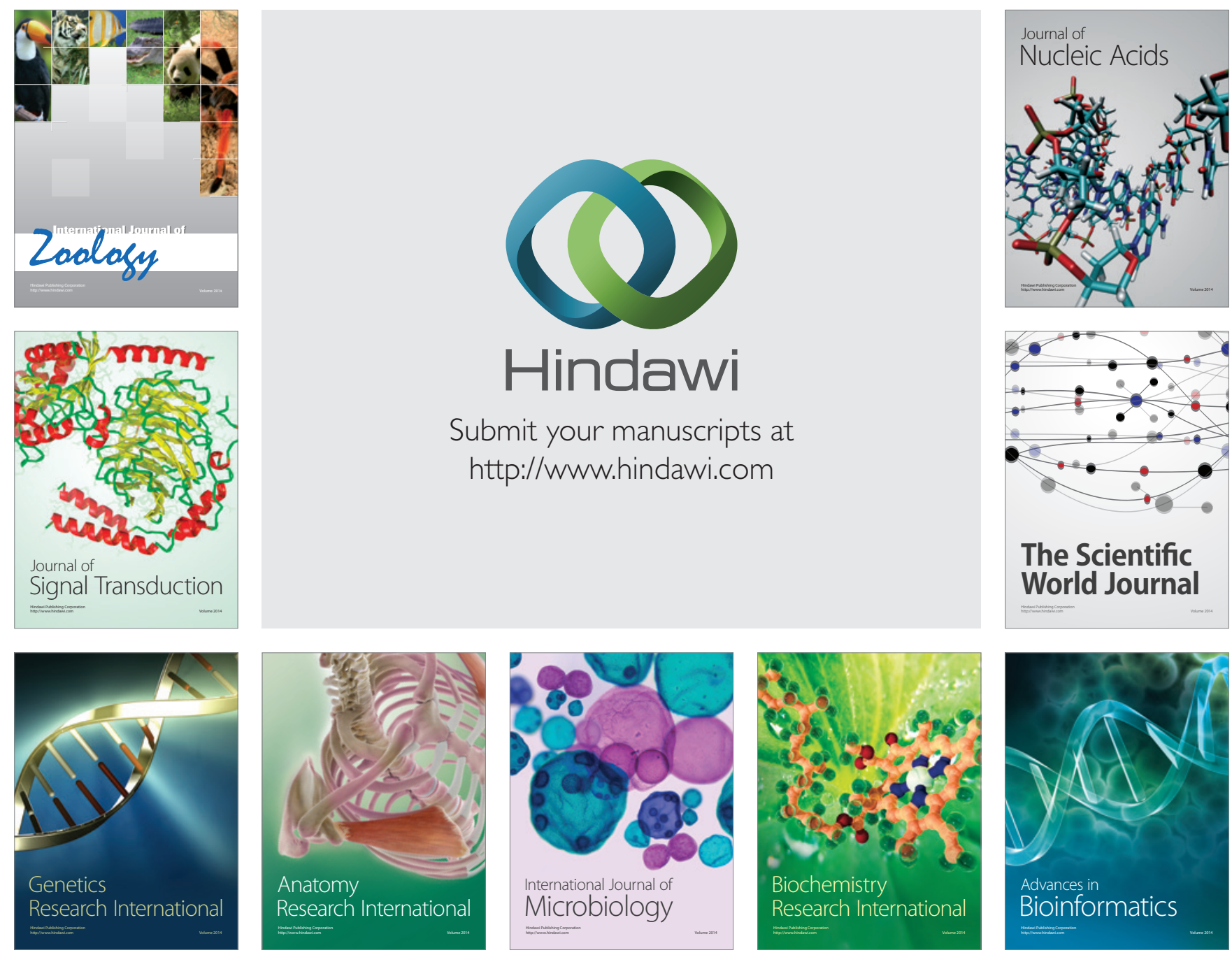

The Scientific World Journal
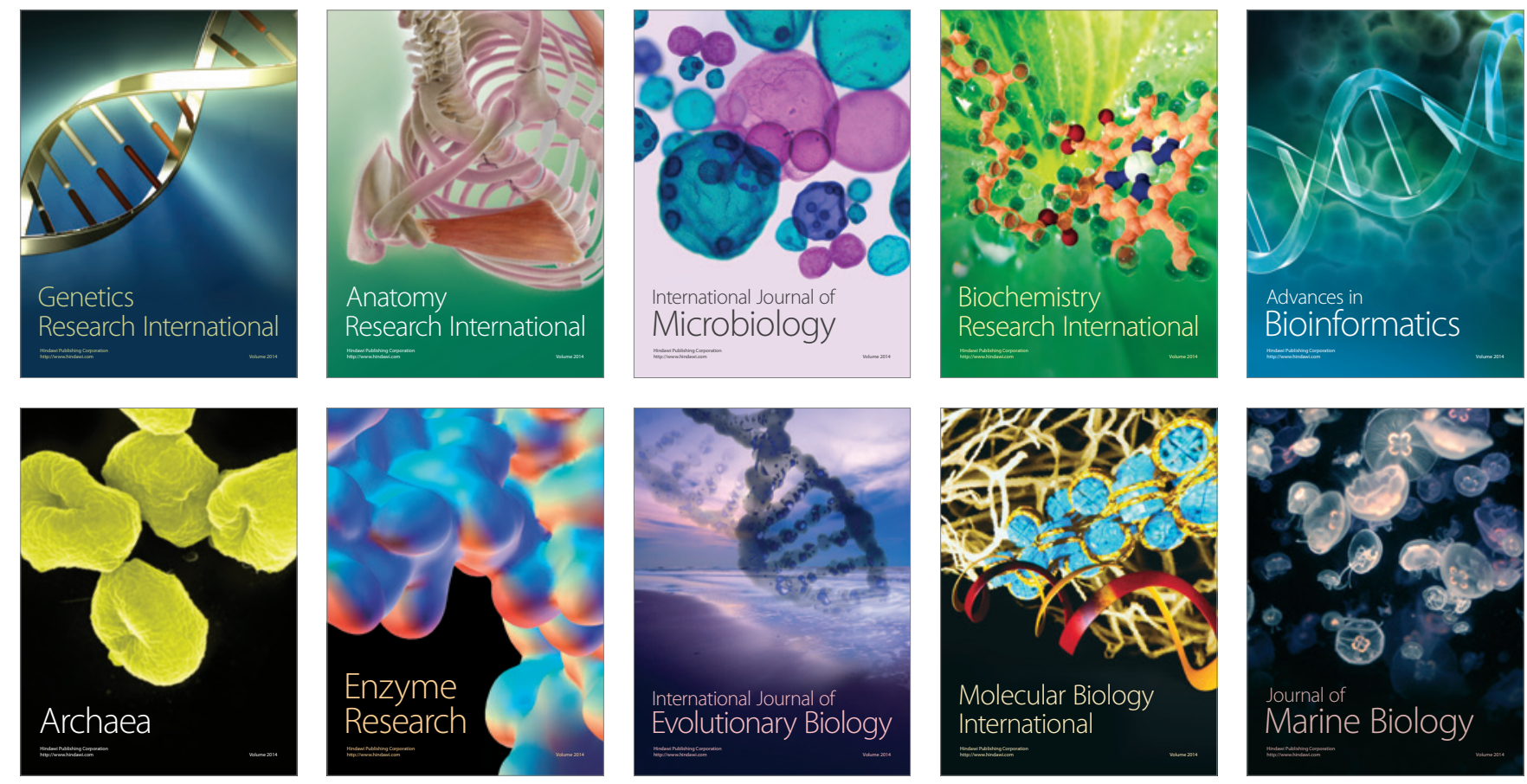